\title{
HUMAN RESOURCE MANAGEMENT IN THE PERSPECTIVE OF THE EXPECTATIONS AND ATTITUDES OF GENERATION Y IN POLAND
}

\author{
Adam Suchodolski \\ Wrocław University of Economics \\ e-mail: adam.suchodolski@ue.wroc.pl \\ DOI: $10.15611 /$ noz.2017.4.05 \\ JEL Classification: J21, M12, M51
}

\begin{abstract}
Summary: The article shows the results regarding the expectations and attitudes towards work of representatives of generation $\mathrm{Y}$ from North America and Poland. The main similarities and differences between both groups in terms of the attitudes towards work are indicated in that article. In interpreting the results of the research it may be concluded that in the analysed area, young people in Poland do not constitute a homogenous group. Moreover, in comparison to their American peers they are generational hybrid shaped by the global trends of mass culture and socialization processes determined by the native culture and system of values. The aim of the article is to formulate the proposals regarding impacts in human resource management towards the Polish representatives of the Y generation adapted to the specificity of their expectations and attitudes.
\end{abstract}

Keywords: Y generation, human resource management, expectations and attitudes towards work.

\section{Introduction}

Cultural and demographic factors are vital determinants shaping the human resource management in companies, one of them is the issue of generational cohorts. Natural demographic processes lead to a situation that in coming years the participation and significance of the so-called Y generation in the total number of employed people in the organizations will increase.

Research on the specificity, features and qualifications of persons included in the $\mathrm{Y}$ generation and on their expectations and attitudes towards work was initiated at the turn of 20th and 21st century using the example of American youth entering the world of work. Problems regarding the engagement and motivating to work of young people, which had been notified by the employers and managers stemming from earlier generational cohorts, were the inspiration for undertaking the research. The differences between the systems of values and perception of professional reality by representatives of different generations were provoking numerous misunderstandings and conflicts at workplace. As a result of exploration with regard to this kind of issues, some of postulative recommendations have been formulated aimed at improving the management of young people.
In the statements of managers from Polish economic organizations, one may also hear about troubles understanding the motives of behaviour of young employees and the difficulties connected with their stimulation. In this context the question arises with regard to the scope of the similarity of the Polish $\mathrm{Y}$ generation between the American one as well as the possibilities of the implementation of the developed patterns of impact towards employees in Poland. One should also learn about the aspects differentiating both generations, and then on the basis of the knowledge and experience relating to the human resource management, construct solutions adjusted to the local circumstances.

Therefore the aim of this article is to formulate the proposals regarding impacts in the human resource management towards Polish representatives of the $Y$ generation adapted to the specificity of their expectations and attitudes.

\section{Specificity of generation $Y$}

The Y generation in the source literature is defined as persons born in the years 1980-2000 [Cewińska et al. 2009, pp. 118-119]. The approved dividing line regarding the birth year of persons recognised as $\mathrm{Y}$ 
generation is obviously very conventional. In terms of persons growing up in Poland, the Y generation may be identified with regard to people born in the last dozen years of the twentieth century ${ }^{1}$.

Apart from the demographic perspective, the $\mathrm{Y}$ generation may be also defined on a sociological basis. It seems that much more significant factors than the year of birth distinguishing the cohort of the $\mathrm{Y}$ generation are specific values and characteristics attributed to the representatives of this community. The values and characteristics specific for the $\mathrm{Y}$ generation were shaped by the social and material environment, within the confines of which the persons included in the given generation were growing up and functioning. The factors of the environment influencing in the most significant way this social group were [Cewińska et al. 2009, p. 120; Podlewska 2015, pp. 23-24]:

- the globalization process and the social as well as economic problems worldwide associated with them, such as: care for the natural environment, multiculturalism of societies, gender equality and freedom movements,

- quickly changing reality resulting from the technical progress and disseminating modern technologies and the development of communi-cation within the transcontinental range,

- widespread accessibility of internet enabling immediate obtainment of current information from different parts of the world,

- popularity regarding communication via social medias,

- possibility of keeping in permanent touch via mobile phones,

- dissemination of mass transport and disappearing of boundaries facilitating movements between distant places in the world.

The consequences regarding the above-mentioned conditions are the substantial turbulence of the environment, the permanent inflow of large amount of information and the increasing pace of life. These factors have resulted in a time deficit regarding reflection, the tabloidization of communication and the superficiality of interpersonal relationships. Thanks to smart phones and satellite communication, the $\mathrm{Y}$ generation maintains permanent contact with people all around the world, obtains current information, meets the needs connected with entertainment and makes purchases. These factors have also shaped the expectations and attitudes of persons from generation $\mathrm{Y}$ towards work and professional reality.

The specificity of those features and preferences in regard to the representatives of the $\mathrm{Y}$ generation was noticed in the USA at the beginning of the 21 st century. While analyzing the source literature and the results of the research conducted in North-American society we may distinguish the following expectations and attitudes towards work, specific for this generation. For young Americans more important than work is private life, free time, the realization of their own passions, social relationships, travel, physical activity and taking care of themselves, pursuing the achievement of harmony between all areas of life and rejection of workaholism. Loyalty towards the employer is not a significant value and they perceive a company in the short-time perspective. They expect from the company to adapt to the needs of employees. They have little tolerance for the imposed conditions and inflexible working hours. They want to 'be', and not only to possess, carrying out interesting tasks of major importance and at the same time avoiding monotony and boredom. They are task-oriented and want to achieve their own goals as well as the possibility of personal development. For them, attractiveness of work is associated with the volatility, dynamism and diversity of the tasks and the execution of many tasks at the same time. They value freedom and independence and are not interested in making a career in the company. They prefer fixed remuneration. They want to be members of the group, they would like to gain social acceptance and a good atmosphere at work and they care about social image. They are confident and are aware of their self-esteem, they believe in their own self-potential, they are feisty and optimistically-oriented towards surroundings. They are well-educated, they known foreign languages and deal with new technologies very well. They want to learn, gain new experiences and non-work related qualifications, they have great developmental potential. Most important for them are their own goals, they are self-oriented persons. They want from the employers to give them clear goals and organize the work as well as to obtain feedback information from them. The authority of the manager is not a thing that is permanent. They show a great tendency to be mobile in terms of territorial and professional issues. They want to travel, change countries, towns, companies and professions. They do not fear changes, new things and challenges, they show great tolerance of insecurity and are easily adaptable to new situations. They object

${ }^{1}$ According to different authors the time frame of births regarding persons recognised as Y generation are placed in the time interval regarding birth cohorts of 1977-1999 (according to: [Żarczyńska-Dobiesz, Chomątowska, 2014, p. 406]), after 1980 [Stachowska, 2012 , p. 33], in the years 1981-1995 [Podlewska 2015, p. 23], after 1982 [Bednarska-Wnuk 2012, p. 88]). 
to standards, patterns, labels. They are open, tolerant towards people they meet for the first time (on the basis of: [Bohdziewicz 2008, pp. 90-91; Chester 2006; Fazlagić 2010; Myers, Sadaghiani 2010]).

\section{Characteristics, expectations and attitudes towards work of the Polish Y generation}

While taking the assumption that the socialization processes and conditions of the environment shape the characteristics and features of a human [Malewski 2013, p. 36; Szczepański 1972, p. 104], we may suppose that the representatives of the $\mathrm{Y}$ generation raised in Poland should slightly differ from their American peers. This conclusion is confirmed by the results of the research regarding representatives of generation Y conducted in Poland. On the basis of their analysis we may indicate analogies and differences in the approach to work of both peer groups. A list of the similarities and differences regarding the expectations and attitudes towards work of young people from Poland and from North America is presented in Table 1.

A significant aspect distinguishing young people in Poland compared to their peers from other countries is their high level of formal education and professional qualifications. Over $90 \%$ of persons at the age of 25 34 have at least completed upper secondary education, almost $80 \%$ of youngsters decide to study at the university level of education, the percentage of people with tertiary education in Poland in the age group of 30-34 exceeds $40 \%$, over half of young people speak at least one foreign language fluently, Polish youth obtain high results at the OECD's Programme for International Student Assessment (PISA) [cf. Czapiński 2012; OECD 2015; Przytuła 2011, p. 50]. High qualifications of young Poles are one of the most important motives of choosing the places to invest the capital by the foreign investors [Nibbe, Lhermitte 2013, p. 16; Sheehan 2012; UNCTAD 2014, p. 22].

The reasons regarding the occurrence of differences of the $\mathrm{Y}$ generation in Poland and other regions may be the specific social, civilization, cultural,

Table 1. Similarities and differences of expectations and attitudes towards work regarding the Y generation from Poland and North America

\begin{tabular}{|c|c|}
\hline Similar expectations and attitudes towards work & $\begin{array}{l}\text { Expectations and attitudes different for the } Y \\
\text { generation in Poland and in North America }\end{array}$ \\
\hline $\begin{array}{l}\text { - a desire aiming at the situation when the performed work is consistent with their } \\
\text { values and interests, } \\
\text { - maintaining harmony between private and professional life, they do not want to } \\
\text { spend too much time at work, } \\
\text { an expectation aimed at a situation when work conditions are adapted to the } \\
\text { preferences of employees, } \\
\text { - pursuing achievement of a self-creation regarding their own development, } \\
\text { a willingness to have real impact on what is happening at the company, } \\
\text { - a willingness and readiness to run own business, } \\
\text { - an expectation to receive regular remunerations, } \\
\text { - preferring to perform team tasks rather than individual ones, } \\
\text { - maintaining positive social relationships and good atmosphere at work. } \\
\text { - self-perception of themselves as unique persons, original ones, they want their } \\
\text { employer to notice and appreciate this, } \\
\text { good education, knowledge of foreign languages, efficient use of information } \\
\text { technology, } \\
\text { - a willingness to learn and develop, getting to know new things, improving and } \\
\text { changing of qualifications, } \\
\text { - an expectation from the superiors to gain support and give them current } \\
\text { feedback information regarding their work, } \\
\text { - a willingness to travel, getting to know new people from different cultures, } \\
\text { a tendency to change the place and country of residence in order to take up an } \\
\text { - they like change and fast pace of life. }\end{array}$ & $\begin{array}{l}\text { - high positioning in the hierarchy regarding } \\
\text { work and money values placed right after } \\
\text { family and love, } \\
\text { - a readiness to devote much more time to work } \\
\text { and less time to private matters", } \\
\text { paying more attention to the sum of } \\
\text { remuneration, } \\
\text { - a willingness to be settled in exchange for the } \\
\text { obtained results, achieved goals and pursuing } \\
\text { to be promoted at work, } \\
\text { - a significant matter constitutes the certainty to } \\
\text { have work and employment security, } \\
\text { preferring to maintain business relationships } \\
\text { with the superiors rather than friendly ones and } \\
\text { an expectation to manage the group, } \\
\text { preferring to work in Poland rather than } \\
\text { working abroad, } \\
\text { unwillingness to have frequent changes of } \\
\text { work, } \\
\text { lack of interest towards flexible forms of } \\
\text { employment and flexible working hours. }\end{array}$ \\
\hline
\end{tabular}

* According to the OECD data Poles in 2015 worked 1963 hours annually (this is 197 hours more than the average in the OECD countries) [OECD 2017] and they spend 14.4 hours daily on meeting the basic needs and entertainment (average for OECD countries is 15 hours) [OECD 2015, p. 76].

Source: own work on the basis of [Bednarska-Wnuk 2012, pp. 89-93; Cewińska et al. 2009, pp. 122-131; Deloitte 2015; Hays 2014; Kopertyńska, Kmiotek 2014b, pp. 188-195; OECD 2015; Podlewska 2015, pp. 25-27; Stachowska 2012, pp. 41-54]. 
political and economic conditions in which representatives of different communities grew up. By comparing the results of social research conducted in Poland in the mid 1990s we may, for example, notice that the value system of young people of that time is quite similar to the value system of contemporary young people. At that time and today the most appreciated are values such as health, family, work and money. Significant differences have only been noted in the case of increase regarding positioning of friendship relationships and decrease in the importance regarding marriage in the value system of young people today compared to their peers in the $1990 \mathrm{~s}$ [Czapiński 2012].

Moreover the results of some research ${ }^{2}$ indicate that the $\mathrm{Y}$ generation itself in Poland is not a homogenous community. The harmony between a professional life and a private one is vital for $36 \%$ of the examined people, for the remainder it is not a priority. For $59 \%$ of respondents the most important things at work are financial benefits, and for $34 \%$ it is differentiated and interesting work duties. The work is a guarantor of social advancement and prosperity for $39 \%$ of the examined people, and for $46 \%$ it is connected with the possibilities to undergo training and achieve personal development. The feeling of being a valuable and appreciated employee is essential for $54 \%$ of young people; $41 \%$ of the Y generation prefer to work in Poland, and $36 \%$ of them would like to work abroad. For $45 \%$ of respondents it is important to have arranged tasks and time at work, and only 23\% expect autonomy [Deloitte 2015; Hays 2014].

\section{Proposals regarding personnel actions concerning generation $\mathrm{Y}$ in Poland}

When matching the observations regarding the similarities and differences in the expectations and attitudes towards work of the Y generation from North America and Poland, as well as the analogy of the value systems of the Polish Y generation with other generational cohorts and the differentiation within the confines of characteristics and professional preferences in the $\mathrm{Y}$ generation, we can conclude that young people in Poland as regarding their attitude to work constitute a hybrid formed by global trends set by the mass culture and socialization processes determined by the native culture and system of values. Nevertheless the efficiency of the process regarding the management of them requires changes in the implementation of the personnel function compatible with the principles of cross-vergence [Stor 2011, pp. 73-74]. Proposals regarding the modifications of impacts contained in the article ${ }^{3}$ have been presented from the perspective of actions carried out within the confines of human resource management ${ }^{4}$. Moreover, due to the Polish membership of the European Union, all proposals regarding solutions and the internal legal regulations must comply with directives and regulations of the community [Tracz-Krupa 2012].

\section{Preparation of personnel function}

The results of the research indicate that young people in Poland, as opposed to their American peers, do not necessarily pursue to maintain the balance and harmony between their professional and private life. In their value system, work is highly ranked, they devote a lot of time to it and it constitutes an important indicator of life success. Similarly as in the case of their American Y peers, they care about the relations and social reception as well as sensitivity of the company for the needs and expectations of the employees. That is why organizations which would like to acquire and maintain persons from $Y$ generation should pay more attention to the creation of a friendly atmosphere, positive social image and employer branding. Social and image relations is a frequent topic regarding the exchange of information between young people's social-networking forums.

The dissemination of internet communication and discussion forums (including those for employee) allows potential young employees to easily obtain information about the company. That is why the human resource policy of the enterprise has to be more transparent and make it more difficult to conceal information about unwelcome phenomena in the company.

In connection to the growing dynamics regarding social and economic processes as well as the "impatience" and ambitions of generation Y, employers have to shorten the time horizon of planning and increase the participation of young people in terms of their determination regarding directions of actions, also including personnel actions.

\footnotetext{
${ }^{2}$ For example the results of research conducted on the samples of 1128 and 1000 persons at the age of 18-30 by the advisory companies Deloitte Polska and Hays Poland.

${ }^{3}$ Submitted proposals are convergent with the suggestions of other researchers undertaking the issues regarding the management of Y generation in the organization (cf. [Cewińska et al. 2009, pp. 132-133; Fazliagić 2010, pp. 64-66; Kopertyńska, Kmiotek 2014a, pp. 46; Kopertyńska, Kmiotek 2014b, pp. 195]).

${ }^{4}$ Presented actions have been systemized according to the model of personnel management made by T. Listwan [1993].
} 


\section{Selection of employees}

The results of research show that persons included in the $\mathrm{Y}$ generation in Poland present very diversified expectations towards work and the employer, therefore in the process of their acceptance into the organization different forms and methods should be applied. Due to the popularity of using electronic medias by young people it is worth to propagate the recruitment of candidates to work with the usage of social networks and possibility to make applications via internet.

High aspirations connected with the development and promotion and expectations regarding the appreciation of their contribution towards work, notified by the people examined, incline dissemination regarding the recruitment of candidates to work from external sources. This means that each job offer for a managerial or prestigious position should in the first place be directed to employees inside the organization.

Striving for continuous development and taking challenges and the situation on the work market, declared by the representatives of $\mathrm{Y}$ generation, evolving into the direction of employee market force organizations to accept human capital in the selection process oriented to search the employees with developmental potential. It is connected with the necessity to make decisions regarding the employment in the perspective of future job positions and recruitment to work of persons with the qualifications lower than required.

\section{Development of employees}

Young people in Poland are very well educated and they strive for permanent professional training. Similar to their peers from other countries they know foreign languages and they are experts in using information technology. The research indicates that they are aware of their high developmental potential; they have got unconventional life aspirations and declare the willingness to carry out non-business development. Therefore employers with the desire to maintain young people longer in the organization have to identify their specific developmental needs, propose a rich and differentiated training package, as well as to create opportunities to share their qualifications with other members of the team. The options regarding using their talents in the organization should also be adapted to the expectations of young people.

Fast pace of life and turbulent changes in which the $\mathrm{Y}$ generation have grown up, made them dynamic, impatient and requiring continuous stimulation. In order to use these characteristics, companies should encourage work and commission young employees to perform innovative and short-term tasks.

The efficient use of the potential regarding employees from generation $\mathrm{Y}$ also encourages preparation of training of managers with regard to the perception of problems from the perspective of young people, the specificity of stimulation concerning their behaviour and modern tools of knowledge diffusion in the organization.

In order to meet ambitions regarding the fast promotion of young people, companies should make the organizational structures flexible enabling them more dynamic transition inside and between the organizational units.

The Y generation in times of globalization and multiculturalism expects from the company to enable them to work in the international environment and implement a wide range projects of great significance.

\section{Motivating}

Due to the wide differentiation of expectations and attitudes regarding representatives of generation $\mathrm{Y}$ in terms of work and the employer, we should strive for individualization of impulses concerning influence on employees. Depending on the structure and specificity of needs we may create 'menus' enabling the selection of benefits by employees and developmental and training actions adapted to their preferences, priorities and lifestyle.

According to the research, attractive content of the work is the factor which stimulates the motivation of young Poles the most. That is why, if possible, we should eliminate routine and repetitive works, replacing them with challenging tasks.

Contrary to their American peers, for young people in Poland the balance between professional and personal life is not such an essential factor. They are willing to make an increased effort at work, provided that they perceive personal benefit expressed with achievements or remuneration in exchange for results. They want to be appreciated at the workplace both in terms of social as well as material incentives. Therefore, employers should create solutions enabling to obtain fast feedback regarding work results, and also offer remunerations connected with work output and enabling them to move their life standards closer to the ones existing in the highly developed countries.

\section{Evaluation of employees}

Young people brought up in a dynamic environment have got used to the fast and regular acquisition of feedback regarding their actions. At work they also expect frequent feedback regarding the results and 
style of the work. In this connection, companies should consider the possibility to implement stage evaluations, since relying only on annual assessment is for young people too abstracted from the reality. In the evaluation process the role of the superior has to be increased, because he/she shall continuously report his/her remarks and stimulate employees to perform tasks.

Due to the qualifications and aspirations of young people the evaluation should be based on ambitious, but realistic goals, and the achievement of positive results should be connected with an appreciation and personal benefits. Such evaluation has the chance to increase the engagement and efficiency of young people.

\section{Social relationships and management style}

The results of the research indicate that the Y generation in Poland is not particularly interested in making friendly relationships at work or using a nonformal management style. They prefer orderly tasks and do not strive for the obtainment of personal autonomy. The loyalty is understood by them as being fair towards colleagues and not the company. Despite the fact that work and the position in the company constitute for them significant values, they exploit the employer and treat him/her as temporary. Therefore, in order to gain the engagement of the employee, we should always explain cause-effect relationships, in such a way that he/she would understand the significance of his/her work and the way the company operates, as well as have the possibility to express his/ her opinions and suggestions concerning changes.

The nature of the relationships between the superiors and subordinates from the $\mathrm{Y}$ generation is to a great extent influenced by the process of socialization and behaviour. The longer educational period caused the extension of the time regarding dependence on the parents, who had been largely planning and organizing the children's life. Thereby more often difficulties appear with initiative and independence when making decisions. Despite the fact that young people do not see the need to share their private matters with superiors, they prefer a boss who is a determined specialist, explicitly articulating his/her expectations, and simultaneously being an honest, fair, open human that is caring about his/her subordinates. A company that would like to satisfy these perceptions should implement the teaching programmes for leaders and managers focused on coaching.

\section{Conclusions}

The suggestions regarding the impacts, expressed in the article, within the field of human resource management towards Polish representatives of generation Y refer to the practices applied in American conditions as well as to the solutions adapted to local circumstances. The analysis of possibilities of implementations used in the American companies with regard to ways of stimulation of young employees was conducted in the context of comparison relating to the results of research concerning the characteristic expectations and attitudes towards work of the American and Polish generation Y. The identified analogies suggest undertake the actions involving in particular:

- increasing transparency and directness of communication with employees, with common use of modern forms and communication channels,

- creation of friendly atmosphere at work and positive social image of the company,

- redefining of the manager's role towards a fair and inspiring leader, providing support to his/her subordinates while performing their tasks,

- dynamising of conducted processes consisting in the delegation of innovative and short-term tasks, eliminating monotony at work and providing immediate feedback,

- creation of development possibilities for employees, not only professional e but also development, enabling them to satisfy their personal need of self-fulfilment,

- enabling work in a global, intercultural and international environment.

The differences between the American and Polish generation $\mathrm{Y}$, identified in the research conducted in Poland, suggest the necessity to develop specific staffing solutions taking into consideration local circumstances.

The designed impacts should concern:

- implementation of the personnel function according to assumptions of the human capital model,

- creating perspectives in the company with regard to promotion, development and professional selffulfilment,

- construction of identification programmes and development of talents enabling to take advantage of the high qualification potential of Polish employees,

- individualization of attitude and adaptation towards employees' preferences concerning personnel measures, in particular regarding staffing, allocation of tasks and diagnosing of developmental potential, 
- construction of assessment and motivation systems regarding employees binding the results achieved at work with material gratification,

- development and activation of programmes enabling young employees to satisfy the need of appreciation and prestige at a workplace (for instance through taking activities connected with sharing of knowledge and experience or related to innovativeness of employees).

The conclusions and indications contained in this article do not normatively take into consideration several evident conditions. The main one is that the $\mathrm{Y}$ generation is not a homogenous group which is why it is not possible to create universal solutions. The structure of any personnel programmes should always be preceded by the individual preferences of employees. Moreover we should take into account the possibility to change the attitudes and expectations of the $Y$ generation over time due to life and professional experiences. They will definitely influence the changes of a value system and a structure of needs regarding the present representatives of the $\mathrm{Y}$ generation. The next important factor forming the projects regarding personnel actions, taking into consideration attitudes and expectations, is poor knowledge concerning the next generational cohort with regard to persons born after 2000 that will enter the labour market in the nearest future, the so-called $\mathrm{Z}$ generation ${ }^{5}$.

\section{Bibliography}

Bednarska-Wnuk I., 2012, Elastyczność zawodowa w percepcji przedstawicieli pokolenia $Y$, Prace Naukowe Uniwersytetu Ekonomicznego we Wrocławiu, nr 249, pp. 86-94.

Bohdziewicz P., 2008, Kariery zawodowe $w$ gospodarce opartej na wiedzy, Wydawnictwo Uniwersytetu Łódzkiego, Łódź.

Cewińska J., Striker M., Wojtaszczyk K., 2009, Zrozumieć pokolenie $Y$ - wyzwanie dla zarzadzania zasobami ludzkimi, [in:] Juchnowicz M. (ed.), Kulturowe uwarunkowania zarzadzania kapitałem ludzkim, Oficyna Wolters Kluwer Business, Kraków.

Chester E., 2006, Młodzi w pracy. Jak zadbać o pracowników z pokolenia $Y$, Wydawnictwo Helion, Gliwice.

Czapiński J., 2012, Przewagi konkurencyjne młodych Polaków, prezentacja na V Konferencji Krakowskiej, http://konferencjekrakowskie.pl/images/prezentacje/V_KK/V_konferencja_ krakowska.pdf (14.08.2017).

Deloitte, 2015, Pierwsze kroki na rynku pracy. Liderzy przyszłości, Deloitte Polska.

Fazlagić J., 2010, Szczególne zjawisko. Pokolenie Y wyzwaniem dla pracodawców, Personel i Zarządzanie, nr 3, pp. 63-66.
Hays 2014, Pokolenie Y a świat pracy. Raport na temat potrzeb zwiazanych z miejscem pracy, postawami i aspiracjami pokolenia Y $w$ Polsce, HAYS Recruiting experts worldwide.

Kopertyńska M.W., Kmiotek K., 2014a, Budowanie zaangażowania pracowników pokolenia $Y$, Prace Naukowe Uniwersytetu Ekonomicznego we Wrocławiu, nr 358, pp. 39-48.

Kopertyńska M.W., Kmiotek K., 2014b, Oczekiwania pracowników pokolenia $Y$ wobec pracodawców i przetożonych - doświadczenia badawcze, Prace Naukowe Uniwersytetu Ekonomicznego we Wrocławiu, nr 349, pp. 185-196.

Listwan T., 1993, Ksztaltowanie kadry menedżerskiej firmy, Mimex, Wrocław.

Malewski M., 2013, Dorostość - kłopotliwa kategoria andragogiki, Teraźniejszość - Człowiek - Edukacja, nr 3(63), pp. 23 -40 .

Myers K.K., Sadaghiani K., 2010, Millennials in the workplace: a communication perspective on Millennials' organizational relationships and performance, Journal of Business Psychology, vol. 25 , pp. 225-238.

Nibbe J., Lhermitte M., 2013, Coping with the crisis, the European way. Ernst \& Young's 2013 European attractiveness sur$v e y$, Studio Ernst \& Young.

OECD, 2015, How's Life? 2015: Measuring Well-being, OECD Publishing, Paris.

OECD, 2017, Hours worked (indicator), https://data.oecd.org/ emp/hours-worked.htm (16.08.2017).

Podlewska E., 2015, Narzędzia budowania relacji preferowane przez pracowników pokolenia $Y$, [in:] Makowiec M (ed.), Wybrane problemy $w$ ksztaltowaniu zachowań organizacyjnych, Wydawnictwo Uniwersytetu Ekonomicznego w Krakowie, Kraków, pp. 23-28.

Przytuła S., 2011, Międzynarodowa kadra menedżerska, Wydawnictwo Uniwersytetu Ekonomicznego we Wrocławiu, Wroclaw.

Sheehan M., 2012, Exploring the link between management development and perceived performance in multinational corporations (MNCs): an analysis of Polish and UK subsidiaries, Zarządzanie Zasobami Ludzkimi, 84(1), pp. 117-134.

Stachowska S., 2012, Oczekiwania przedstawicieli pokolenia Y wobec pracy i pracodawcy, Zarządzanie Zasobami Ludzkimi, 2(85)/12, pp. 33-55.

Stor M., 2011, Strategiczne międzynarodowe zarzadzanie zasobami ludzkimi, Wydawnictwo Uniwersytetu Ekonomicznego we Wrocławiu, Wrocław.

Szczepański J., 1972, Elementarne pojęcia socjologii, PWN, Warszawa.

Tracz-Krupa K., 2012, Wytyczne Unii Europejskiej dla rozwoju kapitalu ludzkiego, [in:] Listwan T., Stor M. (eds.), Sukces w zarzadzaniu kadrami. Elastyczność w zarzadzaniu kapitałem ludzkim, Wydawnictwo Uniwersytetu Ekonomicznego we Wrocławiu, Wrocław, pp. 344-354.

UNCTAD, 2014, Global Value Chains: Investment and Trade for Development, World Investment Report 2013, UNCTAD, New York, Geneva.

Żarczyńska-Dobiesz A., Chomątowska B., 2014, Pokolenie „Z, na rynku pracy - wyzwania dla zarzadzania zasobami ludzki$m i$, Prace Naukowe Uniwersytetu Ekonomicznego we Wrocławiu, nr 350, pp. 405-415.

\footnotetext{
${ }^{5}$ For the time being it is predicted that on the labour market the mutation of the $\mathrm{Y}$ generation called the $\mathrm{Z}$ generation shall soon appear [Żarczyńska-Dobiesz, Chomątowska 2014].
} 


\section{ZARZĄDZANIE ZASOBAMI LUDZKIMI W PERSPEKTYWIE OCZEKIWAŃ I POSTAW POKOLENIA Y}

Streszczenie: W artykule zestawiono wyniki badań oczekiwań i postaw wobec pracy przedstawicieli pokolenia Y z Ameryki Północnej oraz z Polski. Wskazano główne podobieństwa i różnice między obiema grupami w zakresie stosunku do pracy. Interpretując wyniki badań, można konkludować, iż młodzi ludzie w Polsce w analizowanym obszarze nie stanowią grupy homogenicznej. Ponadto w porównaniu z amerykańskimi rówieśnikami są hybrydą pokoleniową kształtowaną przez trendy globalne kultury masowej oraz procesy socjalizacyjne determinowane rodzimą kulturą i systemem wartości. Celem niniejszego artykułu było sformułowanie propozycji oddziaływań z zakresu zarządzania zasobami ludzkimi na polskich przedstawicieli pokolenia Y dostosowanych do specyfiki ich oczekiwań i postaw.

Słowa kluczowe: pokolenie Y, zarządzanie zasobami ludzkimi, oczekiwania i postawy wobec pracy. 